\title{
ARTYKUŁY
}

Klio. Czasopismo poświęcone dziejom Polski i powszechnym

PL ISSN 1643-8191, t. 26 (3)/2013, s. 23-54

(c) (1) $\odot$

DOI: http://dx.doi.org/10.12775/KLIO.2013.032

\section{JolAnta ChOIŃSKA-MiKa}

(Warszawa)

\section{Obywatele u wtadzy: narodziny, rozkwit i zmierzch szlacheckiej republiki}

W

nowej „Podstawie programowej” do przedmiotu „Historia i społeczeństwo. Dziedzictwo epok” znalazł się wątek tematyczny „Rządzący i rządzeni”. Tytuł jest świadomym jest świadomym zapożyczeniem z klasycznej już pracy Antoniego Mączaka ${ }^{1}$, której pierwsze wydanie trafiło do rak czytelników przed blisko 30 laty, a druga, poprawiona i sygnowana przez nowego wydawcę, edycja ukazała się w 2002 r. Autora interesowały zagadnienia związane $\mathrm{z}$ udziałem różnych grup $\mathrm{i}$ warstw $\mathrm{w}$ procesie sprawowania władzy, próbował nie tylko je zrekonstruować, ale również określić przesłanki wiodące ku zróżnicowaniu form i zakresu uczestnictwa w poszczególnych państwach i regionach. Tematem wiodącym pracy, zgodnie z podtytułem, były: władza i społeczeństwo w Europie wczesnonowożytnej. Omówienie tak sformułowanego problemu wymagało podjęcia refleksji wielowątkowej, a zarazem syntetycznej i porównawczej, tylko bowiem po-

${ }^{1}$ A. Mączak, Rzadzący i rzaddzeni. Wtadza i spoteczeństwo w Europie wczesno nowożytnej, Warszawa 1986 (wydanie 2 poprawione i uzupełnione, Wydawnictwo Naukowe Semper, Warszawa 2002). 
łączenie tych trzech perspektyw mogło pomóc zbudować koherentny obraz przemian struktur państwowych odbywających się równocześnie, choć $\mathrm{z}$ różną dynamiką i o specyficznych cechach.

Projektując założenia wątku tematycznego „Rządzący - rządzeni”, autorzy Podstawy programowej inspirowali się ujęciem A. Mączaka, zdając sobie jednak sprawę, że w warunkach szkolnych nie można mechanicznie powtarzać naukowych koncepcji badawczych. Skoncentrowano się więc wokół jednego problemu - uczestnictwa we władzy - rozumianego bardzo szeroko: od rzeczywistej partycypacji do apriorycznego odrzucenia jakiegokolwiek udziału w strukturach instytucjonalnych państwa (stąd w Podstawie programowej pojawiły się zagadnienia związane z ruchem anarchistycznym). Jednocześnie świadomość warunków realizacyjnych, przede wszystkim czasu, którym dysponuje nauczyciel, w naturalny sposób wymusiła ograniczenie listy zagadnień, które przewidziano dla każdego wątku. Zgodnie z koncepcją całego przedmiotu historia i społeczeństwo, poszukiwano zjawisk o znaczeniu wykraczającym poza ramy jednego stulecia. Należą do nich z pewnością, przywoływane we współczesnej debacie publicznej, staropolskie tradycje parlamentarne, do których nawiązano w dwóch punktach wątku „Rządzący - rządzeni”2.

Tekst ten jest próbą syntetycznego przedstawienia najważniejszych problemów związanych z kształtowaniem się zasad, form i mechanizmów umożliwiających obywatelom Królestwa Polskiego, a następnie Rzeczypospolitej Obojga Narodów udział w procesach sprawowania władzy. Przyjmując za punkt wyjścia staropolską definicję obywatelstwa ${ }^{3}$, zawęziłam swoje rozważania do ówczesnych posiadaczy praw politycznych - członków stanu szlacheckiego.

2 W Podstawie programowej do przedmiotu historia i spoteczeństwo nawiązano do nich w dwóch punktach: C.7.1. analizuje funkcjonowanie staropolskiego parlamentaryzmu na tle porównawczym, C.7.2. analizuje i ocenia zjawisko oligarchizacji życia politycznego i rozwoju klienteli jako nieformalnego systemu władzy w I Rzeczypospolitej.

3 Zob. szerzej: S. Grodziski, Obywatelstwo w szlacheckiej Rzeczypospolitej, „Zeszyty Naukowe Uniwersytetu Jagiellońskiego. Prace Prawnicze” 1963, t. 67, z. 12. 
Rozwój praw politycznych i możliwości uczestnictwa we władzy były pochodną przemian zachodzących w Królestwie Polskim równocześnie w kilku obszarach. Charakterystycznym rysem tych przeobrażeń była aktywizacja i wzrost aspiracji politycznych rycersko-szlacheckiego ogółu oraz towarzyszące temu poszerzanie się kręgu osób współuczestniczących w sprawach państwa, a także powiększanie merytorycznego zakresu partycypacji. Zjawiska te legły u podłoża wykształcania się i rozwoju instytucji parlamentarnych, pozwalających na realizację praw politycznych i rzeczywiste współuczestnictwo w kształtowaniu polityki przez ziemiański ogół. Równolegle formowały się mechanizmy komunikacji społecznej pomiędzy politycznym centrum i szlacheckimi wspólnotami ziemskimi, a także w obrębie narodu politycznego. Procesy te zachodziły w konkretnym kontekście ideowym upowszechnianym za pośrednictwem polskiej szkoły prawa, filozofii i myśli politycznej i uczonych z kręgu Akademii Krakowskiej - opartym na tej tradycji, systemie pojęć i sposobie myślenia o państwie oraz relacjach rządzący - rządzeni ${ }^{4}$.

Powyższe zjawiska zachodziły w konkretnych realiach politycznych miały swój kontekst „wydarzeniowy”, w którym istotną rolę odgrywali kolejni władcy, realizowane przez nich projekty i polityczne plany. Opisywane procesy miały również swoją dynamikę i wewnętrzne cezury. Wydaje się jednak głęboko i merytorycznie uzasadnione omawianie przywoływanych zjawisk polityczno-ustrojowych, w tym również problemów związanych z rozwojem systemu parlamentarnego, w dłuższym okresie. Pozwala to bowiem lepiej dostrzec i uwypuklić zjawiska ciągłości, zrozumieć charakter

${ }^{4} \mathrm{Na}$ ten aspekt rodowodu demokracji szlacheckiej zwracał szczególną uwage Henryk Litwin, por.: H. Litwin, W poszukiwaniu rodowodu demokracji szlacheckiej. Polska myśl polityczna w piśmiennictwie XV i początków XVI w., [w:] Między monarchia a demokracja, red. A. Sucheni-Grabowska, M. Żaryn, Warszawa 1994, s. 13-54; K. Ożóg, Król w refleksji uczonych polskich XV wieku, [w:] Król w Polsce w XIV i XV wieku, red. A. Marzec, M. Wilamowski, Kraków 2006, s. 7-39. 
ewolucji instytucji oraz mechanizmów społecznych związanych z jej funkcjonowaniem ${ }^{5}$.

Poszukując rodowodu demokracji szlacheckiej, badacze coraz częściej cofają się aż do schyłku XIV stulecia, do wydarzeń, które miały miejsce w kolejnych dekadach po śmierci Kazimierza Wielkiego. Według Anny Sucheni-Grabowskiej, zmiany dynastii następujące po sobie w stosunkowo krótkim czasie, czyli przez niespełna 30 lat (Piastowie - Andegawenowie - Jagiellonowie), budziły z jednej strony niepokój o przyszłość kraju, z drugiej zaś „wyzwalały [...] instynkt samozachowawczy i pozwalały na wyrabianie się najcenniejszych cech tożsamości polskiej - umiejętności samoorganizowania się $\mathrm{w}$ potrzebie" ${ }^{6}$. W pracach młodszych generacyjnie historyków również zwraca się uwagę na znaczenie doświadczeń politycznych lat 1370-1385 oraz ich długofalowe następstwa, wykraczające poza sferę polityki. Negocjacje towarzyszące kolejnym zmianom na tronie, które można dość dokładnie prześledzić dla lat 1382, 1384, 1385, a także odbywające się w tym czasie zjazdy sprzyjały umacnianiu się poczucia suwerenności poddanych oraz upowszechnieniu koncepcji Corona Regni Poloniae, ugruntowując przekonanie o elekcyjnym charakterze władzy monarszej w Królestwie. Procesy te były elementem przemian zachodzących wówczas w całej Europie Środkowo-Wschodniej, a obserwowanych najwcześniej w Czechach? .

Wyzwania, przed którymi stanęło Królestwo Polskie w ostatniej ćwierci XIV w., były silnym impulsem pobudzającym do działania również rycersko-szlachecki ogół, co przyspieszyło wykształcanie się parlamentarnych

${ }^{5}$ Za takim podejściem opowiadała się w swoich pracach A. Sucheni-Grabowska, Zanim powstanie nowa synteza dziejów Polski, [w:] Rodowód polityczny Polaków, red. T. Gąsowski, A. Waśko, Kraków 2004, a także W. Uruszczak, O periodyzacji historii ustroju dawnej Polski, „Czasy nowożytne” 2002, t. 10 (13), s. 11-19; idem, Historia państwa i prawa polskiego, t. 1: 966-1795, Warszawa 2013, s. 29-33.

${ }^{6}$ A. Sucheni-Grabowska, Przeobrażenia ustrojowe od Kazimierza Wielkiego do Henryka Walezego, [w:] Tradycje polityczne dawnej Polski, red. A. Sucheni-Grabowska, A. Dybowska, Warszawa 1993, s. 19.

7 S. Gawlas, Król i stany w późnośredniowiecznej Europie Środkowo-Wschodniej wobec modernizacji państwa, [w:] Król w Polsce XIV i XV wieku, red. A. Marzec, M. Wilamowski, Kraków 2006, s. 172-174. 
instytucji. Już w latach $1382-1384$ pojawił się też nowy typ zgromadzenia - sejm walny - w którym uczestniczyła nie tylko wąska grupa dygnitarzy państwowych, ale również szlachta nieurzędnicza, a nawet przedstawiciele duchowieństwa i miast ${ }^{8}$. Niewiele później uformowały się sejmy prowincjonalne oraz sejmiki ziemskie. Rozwojowi tych instytucji, ich wrastaniu w krajobraz polityczny Królestwa, sprzyjały bieżące plany polityczne Władysława Jagiełły, a zwłaszcza starania o zapewnienie sukcesji jagiellońskiej oraz potrzeby będące konsekwencją wojny z Krzyżakami. Realizacja tych zamierzeń nie miała szans bez uzyskania poparcia szerszego kręgu szlachty niż tylko wąskiej grupy dygnitarzy, a to z kolei leżało u podłoża kolejnych przywilejów nadawanych przez Jagiełłę. Miały one, podobnie jak akt wydany przez Ludwika Węgierskiego w Koszycach (1374), charakter przywilejów generalnych, obejmujących całą szlachtę, co sprzyjało umacnianiu wewnątrzstanowych więzi opartych na równości praw wszystkich członków stanu, uniemożliwiając zarazem wykształcenie odrębnej grupy szlachty wyższej - arystokracji. Tradycyjnie przedstawiano przywileje jako dowód uszczuplania praw monarchy przez szlachtę, środek do zapewnienia stanowi hegemonii w państwie, a zarazem źródło słabości władzy królewskiej. Współczesna historiografia odrzuciła te opinie jako zbyt uproszczone i nieuwzględniające okoliczności towarzyszących wydawaniu konkretnych aktów. Badacze zwracają obecnie uwagę na fakt, że przywileje nie składały się wyłącznie z uprawnień dla szlachty, ale zawierały również rozstrzygnięcia ważne dla sprawnego funkcjonowania całego państwa ${ }^{9}$. Jednocześnie, o czym często się zapomina, każdy kolejny akt rozszerzał zakres odpowiedzialności szlachty za różne sfery życia państwa: funkcjonowanie wymiaru sprawiedliwości, działalność urzędów ziemskich, precyzował szlacheckie zobowiązania na rzecz obrony i skarbu. W istocie, jak to podkreśla Wacław

${ }^{8}$ H. Samsonowicz, Rola polityczna miast polskich w pierwszej potowie XV w., [w:] Kultura - polityka - dyplomacja. Studia ofiarowane Profesorowi Jaremie Maciszewskiemu w sześćdziesiąta rocznicę Jego urodzin, Warszawa 1990, s. 338-346.

${ }^{9}$ Do takich można zaliczyć choćby postanowienia z Czerwińska (1422), dotyczące zapowiedzi unifikacji prawa, czy też nakaz prowadzenia postępowania sądowego według prawa pisanego. Por.: W. Uruszczak, „Species privilegium sunt due, unum generale, aliud speciale”. Przywileje w dawnej Polsce, „Studia z Dziejów Państwa i Prawa Polskiego” 2008, t. 11 , s. 25 . 
Uruszczak, przywileje generalne „stanowily rezultat umowy społecznej zawieranej z monarchą, w której określano wzajemny zakres obowiązków obu stron"10. Podobne układy były zjawiskiem dość powszechnym w ówczesnej Europie. Beneficjentami każdego aktu była nie tylko szlachta, ale w równym stopniu władca (zyskujący możliwość realizacji konkretnego planu), a także całe państwo. Warto też podkreślić, że nadawane przywileje powiększały zasób dokumentów tworzących zręby polskiego prawa powszechnego, wzmacniały znaczenie prawa pisanego w zarządzaniu państwem, sprzyjały rozwojowi idei nadrzędności ius commune w życiu Królestwa ${ }^{11}$.

Zmieniająca się $\mathrm{w}$ pierwszych dekadach rządów sytuacja polityczno-ustrojowa niosła ze sobą, jak podkreśla Wojciech Fałkowski, również zmiany w sferze idei i języka politycznego, czego najlepszym dowodem było upowszechnianie $\mathrm{w}$ języku politycznym terminu res publica $\mathrm{w}$ znaczeniu szerszym niż tylko kształt terytorialny państwa. Kontekst, w którym go używano, podkreślał nowe treści - podmiotowość narodu polityczne$\mathrm{go}^{12}$, stającego się niezbędnym elementem procesów podejmowania decyzji i tworzenia polityki. Rosnące aspiracje elit i powstającego stanu szlacheckiego znalazły swój wyraz w dążeniach „określenia reguł funkcjonowania państwa niezależnie od panującej dynastii i zainteresowań władcy”'13.

10 Ibidem, s. 26.

11 Wacław Uruszczak uważa jednak, że Władysław Jagiełło nie czuł się skrępowany przywilejami, a to, czy się do nich stosował, zależało od aktualnego układu sił. Monarcha miał silną pozycję i realną władzę, którą zapewniały mu regularne objazdy po kraju i umiejętne wykorzystywanie rywalizacji pomiędzy różnymi grupami możnych. W. Uruszczak, Monarchia Jagiellonów państwem konstytucyjnym, [w:] Dziedzictwo Pierwszej Rzeczypospolitej w doświadczeniu politycznym Polski i Europy, red. J. Ekes, Nowy Sącz 2005, s. 20. Z kolei Wojciech Fałkowski eksponuje odmienne cechy prowadzonej przez Jagiełłę polityki: „wyraźny udział konsultacji, popierania decyzji wspólnych i uwzględniania opcji rady oraz reprezentantów społeczeństwa politycznego"; W. Fałkowski, Idea monarchii w Polsce za pierwszych Jagiellonów, [w:] Polska okoto 1400 roku. Państwo, spoteczeństwo, kultura, red. W. Fałkowski, Warszawa 2001, s. 211.

12 Pojęcie to zdaniem Fałkowskiego dotyczyło: „społeczności szlacheckiej, patrycjatu szybko bogacących się miast, wyższego duchowieństwa i powiększającego się grona uczonych i intelektualistów krakowskich”, W. Fałkowski, op. cit., s. 204.

${ }^{13}$ Ibidem, s. 204. Jednak, jak uważa Uruszczak, aż do połowy XV w. „nie było w państwie stałych instytucji, które by mogły skutecznie gwarantować szlachcie rze- 
Jednak, jak dość zgodnie uznają badacze, rzeczywisty udział we władzy należał w tym okresie do możnowładczej elity, oligarchii rekrutującej się głównie z rodów małopolskich ${ }^{14}$. Aktywizacja szlacheckiego ogółu miała swój wymiar instytucjonalny w postaci szybko rozwijających się sejmików i sejmu. Funkcjonowanie tych instytucji w czasach pierwszych Jagiellonów nie miało jeszcze cech utrwalonego i uporządkowanego systemu. Sejmy walne działały równolegle lub naprzemiennie z sejmikami ziemskimi lub sejmami prowincjonalnymi. Współistnienie, równoczesność występowania obu typów zgromadzeń była charakterystycznym rysem dla pierwszej połowy XV stulecia. Nie wykrystalizowały się jeszcze ramy formalne, struktura zgromadzeń czy zasady uczestnictwa. W zjazdach brali udział urzędnicy, przybywała również szlachta, choć dość długo jej rola była ograniczana przez elitę dygnitarzy. Obrady toczyły się przede wszystkim w gronie rady królewskiej powiększonej o urzędników ziemskich. Niekiedy towarzyszyły im reprezentacje szlachty i miast. Na ogół to w gronie rady zapadały kluczowe decyzje, a od zgromadzonego rycerstwa oczekiwano aklamacyjnego przyjęcia podjętych przez radę ustaleń. Jednak, jak pisze Juliusz Bardach, już za rządów Władysława Jagiełly pojawiły się wyráne tendencje emancypacyjne wśród ziemiańskiego ogółu, których dowodem były sejmy obozowe odbywające się przy okazji zwołania pospolitego ruszenia, a także rozwój sejmików ziemskich ${ }^{15}$. W pierwszej dekadzie XV stulecia sejmiki ziemskie działały na ziemiach Wielkopolski i Małopolski. Aktywizacja lokalnych zgromadzeń, „włączanie do rywalizacji o udział we władzy przedstawicieli communitates - korporacji ziemskich"16, miała zasadniczy wpływ na dalszy rozwój systemu politycznego Królestwa, przyspieszała ewolucję

czywisty udział we władzy i umożliwiać obronę zdobytych uprawnień”; W. Uruszczak, Monarchia Jagiellonów..., s. 20.

${ }^{14}$ S. Gawlas, op. cit., s. 176; W. Uruszczak, Monarchia Jagiellonów... s. 20-21.

15 Już w 1404 r. Jagiełło odwołał się do sejmików, prosząc o uchwalenie podatków na wykup ziemi dobrzyńskiej z rąk Zakonu. Por. J. Bardach, Początki sejmu, [w:] Historia sejmu polskiego, t. 1: Do schytku szlacheckiej Rzeczypospolitej, red. J. Michalski, Warszawa 1984, s. 23-32.

16 S. Gawlas, op. cit, s. 176. 
ustrojową od „monarchii nierównoprawnych stanów” (używając określenia Antoniego Gąsiorowskiego) ${ }^{17}$ ku tzw. demokracji szlacheckiej.

Skąpa liczba zachowanych wzmianek, z których najstarsze pochodzą z lat sześćdziesiątych XV w., nie pozwala nam na rekonstrukcję wielu istotnych elementów działania sejmików w epoce pierwszych Jagiellonów. Nie wiemy, jak liczne były to zgromadzenia, czy i jakie obowiązywały w nich procedury i zwyczaje, jak podejmowano decyzje. Nie mamy natomiast wątpliwości, że w chwili obejmowania tronu przez Kazimierza Jagiellończyka sejmiki były już trwałym elementem ustrojowym Królestwa. Ich znaczenie zostało wzmocnione decyzjami podjętymi u progu wojny trzynastoletniej na zjazdach w Cerekwicy, Opokach i Nieszawie. Dla badaczy dziejów polskiego ustroju przywileje cerekwicko-opocko-nieszawskie - doprecyzowywane przez kolejne miesiące aż do 1456 r. - stanowiły, cytując za Juliuszem Bardachem, „szlachecką kartę wolności” ${ }^{18}$. Obligując monarchę do uzyskania zgody sejmików ziemskich na zwołanie pospolitego ruszenia i ustanowienie podatków, przenosiły punkt ciężkości procesu decyzyjnego z sejmu walnego, na którym prym wiedli dygnitarze, na sejmiki ziemskie. Tę ugruntowaną w historiografii tezę zakwestionował ostatnio Roman Sobotka ${ }^{19}$, dowodząc, że przywoływane przywileje nie zmieniły zasadniczo wcześniejszej praktyki, a „przypisywanie istotnej roli sejmikom ziemskim w tej epoce wynikać może z nieustalonej terminologii łacińskiej" ${ }^{20}$, braku konsekwencji terminologicznej i występowania w źródłach tych samych nazw w odniesieniu do różnych typów zgromadzeń. Badacz dostrzega co prawda aktywizację zgromadzeń ziemskich i poszerzanie się merytorycznego zakresu podejmowanych przez nie tematów, ale uważa, że były to zagad-

17 A. Gąsiorowski, Monarchia nierównoprawnych stanów, [w:] Polska dzielnicowa i zjednoczona, red. A. Gieysztor, Warszawa 1972.

${ }^{18}$ J. Bardach, op. cit., s. 32.

19 R. Sobotka, Między monarchiq stanowa a demokracja szlachecka. Znaczenie przywilejów nieszawskich w periodyzacji dziejów Polski, „Zeszyty Prawnicze UKSW” 2011, t. 11.4 , s. 67-101.

20 „Określeniem conventio (lub conventus) generalis nazywano i sejm walny, i sejm prowincjonalny. Te ostanie nazywane były także conventio (lub conventus) particularis, które to określenia stosowano czasem do sejmików ziemskich. Do nich jedynie stosowano nazwę conventio terrestris"; ibidem, s. 95. 
nienia o charakterze lokalnym. Problemy ogólnopolskie, a do takich należy zaliczyć sprawy podatków czy pospolitego ruszenia, nie były, zdaniem Sobotki, rozstrzygane przez sejmiki.

Niewątpliwie problem wymaga pogłębionych badań. Stojąc jednak na gruncie ustaleń starszej historiografii, można przypuszczać, że przekazanie decyzji podatkowych na poziom lokalnych zgromadzeń stało się ważną okolicznością stymulującą rozwój instytucji sejmów prowincjonalnych $^{21}$, które w drugiej połowie XV stulecia stały się ważnym ogniwem pośredniczącym w systemie komunikacji między wspólnotami ziemskimi a monarchą 22 . Wspólne obrady w Kole czy Korczynie, o tematyce których decydowała szlachecka communitas, sprzyjały integracji politycznej w obrębie prowincji. Konieczność porozumiewania się, konfrontowania potrzeb regionu z zamierzeniami władcy ${ }^{23}$, negocjowania wspólnego stanowiska wobec postulatów monarszych - zwłaszcza w kwestiach podatkowych umacniały poczucie więzi pomiędzy ziemiami. Towarzyszyło temu wykształcanie się instytucji prawnej pełnomocnictwa (znanej z prawa kanonicznego) - upowszechnianie praktyki wysyłania przez wspólnoty ziemskie reprezentantów z mocą decydowania o podatkach w imieniu całej communitatis $^{24}$. Najstarsza wzmianka na temat udziału posłów w sejmie dotyczy sejmu koronacyjnego z 1434 r., a następnie 1435 r. Praktyka wysyłania delegatów wybranych wcześniej na sejmikach ziemskich rozwinęła się za

${ }^{21}$ Obszar działania poszczególnych sejmów prowincjonalnych określił statut Kazimierza Jagiellończyka wydany na sejmie w Piotrkowie w 1456 r. Małopolska - szlachta województw krakowskiego, sandomierskiego, lubelskiego oraz ruskiego - zbierała się w Nowym Mieście Korczynie. Z kolei województwa prowincji wielkopolskiej - poznańskie, kaliskie, sieradzkie, łęczyckie, brzesko-kujawskie i inowrocławskie oraz ziemia dobrzyńska - odbywały sejmy prowincjonalne w Kole.

22 Jak pisze Juliusz Bardach, „zamiast wysyłać legatów do każdego sejmiku ziemskiego z osobna, zaopatrując go w listy wierzytelne oraz legację z propozycjami uchwał, Kazimierz Jagiellończyk wolał gromadzić razem szlachtę całej prowincji i przybyć na zjazd osobiście” (J. Bardach, op. cit., s. 35), co czynił dość często - badania Antoniego Gąsiorowskiego potwierdziły obecność króla m.in. na sejmach prowincji wielkopolskiej w latach: 1457, 1463, 1468, 1472, 1474, 1489, 1485.

23 W. Fałkowski, Idea monarchii..., s. 214.

${ }^{24}$ W. Uruszczak, Poselstwo sejmowe $w$ dawnej Polsce. Postaniec, mandatariusz, poset narodu. „Czasopismo Prawno-Historyczne” 2009, t. 61, z. 1, s. 47-63. 
panowania Kazimierza Jagiellończyka, co jest wiązane z przywilejami cerekwicko-opocko-nieszawskimi oraz ze wzrostem znaczenia sejmu walnego. Zbierając się w miarę regularnie, często dwa, a nawet wyjątkowo trzy razy w roku, stał się on - zdaniem Wojciecha Fałkowskiego - „instytucją po części zarządzającą państwem"25.

Coraz częstsze uczestnictwo w obradach sejmowych upełnomocnionych reprezentantów sejmików ziemskich doprowadziło z czasem do uformowania się odrębnego koła poselskiego, zapoczątkowując podział sejmu na dwie izby. Wedle Wacława Uruszczaka nastąpiło to już w 1468 r., a więc znacznie wcześniej aniżeli jest dość powszechnie przyjmowane ${ }^{26}$. Krakowski badacz krytycznie odniósł się do ustaleń dawniejszej historiografii, dowodząc, że w dziejach instytucji sejmu walnego tradycyjnie podawana data 1493 r. - „nie miała praktycznie żadnego znaczenia” ${ }^{27}$.

Nie rozstrzygając $\mathrm{w}$ tym miejscu, która $\mathrm{z}$ interpretacji jest bliższa prawdzie, warto jednak podkreślić ewolucyjny charakter formowania się instytucji oraz fakt, że po 1493 r. wszystkie kolejne zgromadzenia miały już dwuczłonową strukturę. Można więc uznać, że u schyłku XV stulecia proces formowania się zrębów polskiego parlamentaryzmu na dwóch poziomach - lokalnym i ogólnopaństwowym - dobiegł końca. Doprecyzowały się kompetencje różnych typów zjazdów, a także relacje między nimi. Sejmy prowincjonalne stały się sejmikami generalnymi. Utrwaliła się geografia sejmikowa - miejsca odbywania sejmików - która z niewielkimi zmianami przetrwała kolejne stulecia. Uformowały się struktura i skład sejmu walnego, a także procedury związane z jego zwoływaniem oraz obradami.

25 W. Falkowski, Idea monarchii..., s. 215. Za Kazimierza Jagiellończyka niemal co roku, a w przypadku niektórych władców odbywały się nawet dwa razy w roku; w 1459 r. - wyjątkowo trzy razy. Zestawienia wszystkich sejmów za Kazimierza Jagiellończyka dokonał idem, Rok trzech sejmów, [w:] „Aetas media, aetas moderna”. Studia ofiarowane prof. Henrykowi Samsonowiczowi w 70 rocznicę urodzin, Warszawa 2000, s. 438.

${ }^{26}$ Utarło się bowiem wiązać początki dwuizbowego sejmu z sejmem, który odbył się w Piotrkowie od 28 stycznia do 3 marca 1493 r., a który poprzedziły przedsejmowe sejmiki ziemskie w poszczególnych ziemiach.

27 W. Uruszczak, Najstarszysejm walny koronny,,dwuizbowy” w Piotrkowiew 1468 roku, http://www.law.uj.edu.pl/ - khpp/site/images/adm/Image/NAJSTARSZY\%20SEJM\%20 WALNY\%20KORONNY\%20-\%2026\%20V\%20011.pdf, s. 18 (dostęp: 12.04.2013). 
Wykształciły się zasady pełnomocnictwa sejmowego - mandatu poselskiego. W wyniku wieloletnich przeobrażeń powstała zhierarchizowana konstrukcja ustrojowa, pozwalająca łączyć formy właściwe demokracji reprezentacyjnej (sejm walny) z rozwiązaniami gwarantującymi bezpośrednią partycypację obywateli (sejmiki).

Ewolucji instytucjonalnej towarzyszyły przemiany w sferze ideowej, upowszechnianie systemu pojęć, języka politycznego i wartości dotyczących funkcjonowania państwa. Państwo przestało być domeną władcy, a stało się sprawą publiczną (res publica), szerzej - wspólnotą splecioną prawami i obowiązkami. W tym znaczeniu obecne było w refleksji akademickiej w drugiej połowie XV w., stopniowo i różnymi drogami przenikając do świadomości powszechnej. Za pośrednictwem uczonych z kręgu Akademii Krakowskiej, Stanisława ze Skarbimierza, Mikołaja Kozłowskiego, Stanisława z Dąbrówki, Jana z Dąbrówki czy Pawła Włodkowica, była recypowana na grunt polski - sięgająca korzeniami starożytności, a rozwinięta przez Jana z Salisbury, Tomasza z Akwinu i jego uczniów - koncepcja państwa jako organizmu, którego poszczególne członki mają do spełnienia konkretną, właściwą sobie rolę. Refleksja ta, jak dowodzi Krzysztof Ożóg, była bardzo mocno związana z realiami i aktualnymi wyzwaniami (spór polsko-krzyżacki) monarchii jagiellońskiej ${ }^{28}$.

W dyskursie uczonych, szczególne miejsce przypadało głowie - królowi, strażnikowi ładu, bezpieczeństwa i dobra poddanych, któremu przypisywano również dość obszerny katalog uprawnień i powinności. Tworzyły one zbudowany na fundamencie czterech cnót kardynalnych - roztropności, sprawiedliwości, umiarkowaniu i męstwa - wizerunek władcy mądrego i rozważnego, związanego w swych działaniach przysięgą złożoną w czasie koronacji, a tym samym - prawem ${ }^{29}$. W uniwersyteckiej refleksji kwestie te spłatały się ze sobą - przysięga koronacyjna i towarzyszące jej potwierdzenie praw Królestwa wyznaczały granice działań monarchy, gwarantując prawu supremację w państwie ${ }^{30}$. Faktyczna pozycja władcy zależała jednak

${ }^{28}$ K. Ożóg, op. cit., s. 7-39.

${ }^{29}$ Wątek ten był szczególnie mocno obecny w pismach Pawła Włodkowica; por. ibidem, s. 17, gdzie obszerna bibliografia.

${ }^{30}$ H. Litwin, op. cit., s. 22. 
w dużej mierze od jego indywidualnych cech, żadna bowiem sformułowana na piśmie sankcja prawna nie gwarantowała składanych przy koronacji zobowiązań do zachowania praw i wolności. I jak pokazała praktyka choćby „autorytarnych” ${ }^{31}$ rządów Jana Olbrachta, możliwości prowadzenia samodzielnej polityki, odstępowania od ustalonych zasad, gdy zdało się to królowi konieczne lub użyteczne, były dość duże.

Doświadczenia ostatniej dekady XV stulecia miały istotny wpływ na postawę elit koronnych w czasie bezkrólewia i elekcyjnych negocjacji po śmierci Olbrachta. Przedstawione elektowi, Aleksandrowi Jagiellończykowi, artykuły $^{32}$, zwane od miejsca rokowań mielnickimi, bardzo mocno podkreślały obowiązki monarchy, przede wszystkim konieczność respektowania prawa i rządzenia zgodnie z dobrem powszechnym. Pomyślane jako zabezpieczenie przed rządami króla tyrana, przyznawały Radzie Królewskiej rolę gwaranta praworządności poczynań władcy. Wprowadzały sankcje na wypadek bezprawnych działań monarchy, przewidując zarazem różne formy protestacji i stawienia oporu władcy. Dokument normował zasady nominacji na urzędy państwowe, a insygnia królewskie powierzał (co było nowościa) wspólnej pieczy senatorów wyższych. Ograniczał swobodę władcy w zakresie bicia pieniądza, formułując dość dokładnie wielkość, rodzaj i wartość monet, przyznając senatorom prawo nadzoru nad polityką menniczą władcy. Artykuły wzmacniały niewątpliwie pozycję senatorów występujących w roli strażników króla oraz prawa i z tego powodu przez wiele dziesięcioleci funkcjonowały w powszechnej świadomości jako przywilej dla senatu, ustanawiający rządy oligarchii magnackiej. W świetle współczesnych badań pogląd ten wymaga rewizji. Krytyczna analiza treści poszczególnych zapisów odsłania bowiem nie tylko olbrzymi ładunek ideowy, odwołujący się wprost do chrześcijańskiej myśli polityczno-prawnej, ale również pro-

31 W. Uruszczak, Monarchia Jagiellonów..., s. 22.

32 W historiografii używana jest również nazwa „przywilej mielnicki”. Szczegółowa analiza historyczno-prawna dokumentu w: L. Sobolewski, W. Uruszczak, Artykuty mielnickie z roku 1501, „Czasopismo Prawno-Historyczne” 1991, t. 42, z. 1-2, s. 51-79. 
gram naprawy państwa, dążenie do przywrócenia prawu nadrzędnej roli, regulującej funkcjonowanie państwowego organizmu. Artykuły mielnickie, będące cennym świadectwem późnośredniowiecznej myśli ustrojowej, nie stały się jednak „ustawą zasadniczą” królestwa jagiellońskiego. Aleksander Jagiellończyk nie zaprzysiągł ich w czasie koronacji. Wydane jedynie pod litewską pieczęcią, były - jak twierdzą Ludwik Sobolewski i Wacław Uruszczak - wyłącznie osobistym zobowiązaniem monarchy ${ }^{33}$. Zostawiając na boku spór o interpretację artykułów, warto podkreślić, że akcja senatorskiej elity, wyraźnie dostrzegalne oznaki dążeń do utrzymania dominacji w państwie, zmobilizowały średnią szlachtę do działania. Efektem podjętej kontrakcji były decyzje sejmu z 1504 r. - zwołany z inicjatywy sejmików ziemskich zjazd ograniczył swobodę króla w zakresie dysponowania dobrami domeny monarszej oraz nadawania urzędów ${ }^{34}$, zakazując jednocześnie łączenia urzędu kanclerza z innymi godnościami. Niepołączalność (incompatibilitas) stanowisk miała zapobiec kumulacji władzy w rękach wąskiej elity. Podjęte w Piotrkowie uchwały były dowodem antysenatorskich nastrojów wśród szlachty, a zarazem zwiastunem kolejnej fali aktywizacji i dążeń emancypacyjnych stanu szlacheckiego. Krótki okres rządów Aleksandra okazał się czasem ostatecznego „dookreślania” miejsca poszczególnych instytucji w systemie politycznym państwa. Fundamentalne dla tego procesu znaczenie miały decyzje sejmowe podjęte na sejmie radomskim w 1505 r. W ciągu ponad dwumiesięcznych obrad ${ }^{35}$ zjazd ten uchwalił kilkadziesiąt ustaw, ale tylko jedna z nich, tzw. konstytucja nihil novi, na trwałe weszła do podręczników historii, stając się jednocześnie ważną cezurą w dziejach Polski, a zwłaszcza dziejach jej ustroju.

Na mocy aktu uchwalonego 30 maja, w którym zapewniano, że „nihil constitutui debeat per nos et successores nostros sine communi consi-

33 Ibidem, passim.

34 Zakazano zastawiania dóbr ziemskich poza sejmem i bez zgody senatu. Postanowiono, że urząd kanclerza może być nadany przez króla jedynie za radą senatorów na sejmie walnym, a podskarbi, który nie będzie w swej działalności uwzględniał uchwał rady królewskiej, może zostać pozwany przed sąd sejmowy.

35 Sejm został zwołany na 9 lutego, ale rozpoczął obrady 30 marca 1505 r. Por.: W. Uruszczak, „Sejm walny wszystkich państw naszych”. Sejm w Radomiu z 1505 roku i konstytucja „Nihil novi”, „Czasopismo Prawno-Historyczne” 2005, t. 57, z. 1, s. 11-27. 
liariorum et nuntiorum terrestrium consensu”, sejm walny zają centralne miejsce w systemie ustrojowym państwa, a stanowienie prawa przestało być wyłączną domeną władcy, stając się, zgodnie z tekstem aktu, sferą współdziałania $^{36}$ monarchy z parlamentem, czyli reprezentacją narodu politycznego Królestwa. Wedle wielu badaczy, konstytucja stworzyła ustawowy fundament demokracji szlacheckiej. Jednocześnie, na co zwraca uwagę Wacław Uruszczak, konstytucja nihil novi formalizowała znamienną ewolucję systemu politycznego Królestwa Polskiego - przekształcanie się monarchii arystokratycznej (oligarchicznej), jaką było w czasach rządów pierwszych Jagiellonów ${ }^{37}$, w nowożytną monarchię parlamentarną (elekcyjno-parlamentarną, jak uważa Anna Sucheni-Grabowska) ${ }^{38}$. Praktyka jednak jeszcze dość długo odbiegała od zapisów i rozstrzygnięć prawnych. Choć w konstytucji nihil novi w równorzędny sposób potraktowano senatorów i posłów ziemskich, to do faktycznej równości obu izb droga była jeszcze stosunkowo daleka. Dużą rolę odgrywała postawa władców. Zygmunt I co prawda zwoływał sejmy z dużą częstotliwością, średnio co 10 miesięcy ${ }^{39}$, ale jednocześnie uważał to za zło konieczne i starał się zredukować rolę sejmu, a zwłaszcza izby poselskiej, do uchwalania podatków. Jednak nie powiodły się próby trwałego ograniczenia aktywności reprezentantów ziemskich i pozbawienia ich rzeczywistego udziału w sprawach państwa. Stosunkowo szybko, bo już od $1520 r{ }^{40}$ poczęły ujawniać się nastroje opozycyjne, wzmacniane w miarę upływu lat rosnącym niezadowoleniem z braku pozytywnej reakcji monarchy na postulaty ruchu szlacheckiego, wśród których najważniejsze miej-

36 Wacław Uruszczak uważa, że treść konstytucji podkreślała nadrzędność ius commune, którego zasady nie mogły być uchylane i zmieniane bez zgody trzech stanów - króla, senatu, izby. Natomiast król nadal zachowywał władzę stanowienia prawa w sprawach nieuregulowanych przepisami prawa pospolitego, por. idem, Zasada "lex est rex" $w$ Polsce XVI wieku, „Śląski Kwartalnik Historyczny Sobótka” 1993, R. 48, z. 2-3, s. 149-157.

${ }^{37}$ Idem, Monarchia Jagiellonów, s. 19-24.

38 Wielkim osiągnięciem sejmu radomskiego z 1505 r. było zlecenie kanclerzowi wielkiemu Janowi Łaskiemu zredagowania i opublikowania zbioru prawa pospolitego. Zbiór ten ukazał się już rok później - będąc wspaniałym dokumentem myśli prawniczej, odegrał olbrzymią rolę w upowszechnianiu znajomości prawa wśród szlachty.

39 W całym okresie panowania Zygmunta I odbyły się 42 sejmy.

40 T. Szulc, $Z$ badań nad egzekucja praw, „Studia z Dziejów Państwa i Prawa Polskiego" 2000, nr 6. 
sce zajmowała początkowo „naprawa praw”. Niepokój wzbudzała również elekcja małoletniego Zygmunta Augusta. Doszło do niej co prawda za zgodą senatu, izby i samego króla, a - jak sugerują źródła - współcześni nie kwestionowali legalności dokonanego wyboru, ale odbyła się ona w sposób odbiegający od wcześniejszych zasad ${ }^{41}$. Niemniej jednak fakt potwierdzenia na sejmie koronacyjnym w marcu 1530 r. nienaruszalności zasad elekcji świadczy, że zainspirowana przez Bonę Sforzę akcja wyniesienia małoletniego królewicza na tron budziła też negatywne emocje. Warto dodać, że już sam fakt ustawowego potwierdzenia elekcyjności tronu, wprowadzenie zwyczaju do prawa pisanego, stanowił olbrzymie osiągnięcie, potwierdzające w praktyce przekonanie, że w Polsce lex est rex.

Najmocniejszym akordem narastającego w latach trzydziestych napięcia politycznego był rokosz lwowski z 1537 r., który udowodnił determinację szlachty. Król, dążąc do uspokojenia nastrojów w kraju, na sejmie piotrkowskim w 1538 r. zaakceptował szlacheckie postulaty ${ }^{42}$. We wstępie do uchwalonych w Piotrkowie konstytucji sejmowych monarcha przyznał się do naruszania prawa, deklarując solennie, że takie akty nie powtórzą się w przyszłości (,że nigdy my ani nasi następcy nie pozwolimy na coś takiego"). Szereg szczegółowych zapisów ograniczał swobodę monarchy w dziedzinie nadawania urzędów, przyznając sejmowi i sejmikom prawo wzywania do ustąpienia z urzędu senatorów trzymających starostwa wbrew prawu o incompatibilitas. W odrębnym punkcie zagwarantowano na przyszłość wolną elekcję z udziałem szlachty ${ }^{43}$, co było istotnym sukcesem szlacheckich działaczy. Przywoływana bowiem wcześniej konstytucja z 1530 r. oddała decydujący głos w tej sprawie senatowi. Warto dodać, że zapisy wpro-

41 Wybór dziesięcioletniego królewicza został dokonany na sejmie zwykłym zwołanym dla zabezpieczenia bezpieczeństwa państwa bez wcześniejszego powiadomienia potencjalnych uczestników elekcji. Wyboru dokonano za życia panującego monarchy, co było pierwszym tego rodzaju wypadkiem w historii Królestwa Polskiego.

${ }^{42}$ Konstytucje sejmu piotrkowskiego z 1638 r., Volumina Legum, wyd. J. Ohryzko, t. 1, Petersburg 1859, s. 255-266 (516-540).

43 Ibidem, s. 254 (516). 
wadzone na sejmie krakowskim i piotrkowskim stały się później podstawą elekcji virition $\mathrm{w} 1573 \mathrm{r}^{44}$

Po rokoszu lwowskim aktywność szlachecka przybrała coraz bardziej zinstytucjonalizowaną formę stronnictwa sejmowego, posiadającego koherentny program refom i zdeterminowanych liderów. Hasła egzekucji praw i dóbr zostały wzmocnione przez dodatkowe postulaty dotyczące funkcjonowania państwa oraz integracji jego terytorium. Program egzekucjonistów i przebieg sejmowych sporów o egzekucję został dość dobrze omówiony w literaturze ${ }^{45}$, aczkolwiek jeszcze ciągle wiele tematów szczegółowych czeka na wyjaśnienie lub rozwinięcie. Odsyłając do tych badań, warto w tym miejscu podkreślić, że siłą programu była jego różnorodność, wieloaspektowość, co pozwalało różnym grupom szlachty identyfikować się z działalnością przywódców. Podejmowane przez nich akcje przynosiły korzyści wszystkim szlachetnie urodzonym mieszkańcom Królestwa, a w sferze życia politycznego, na co zwróciła uwagę Irena Kaniewska, „zmierzały do zdemokratyzowania stosunków” ${ }^{46}$. Jednak niezależnie od determinacji szlachty i jej liderów w izbie poselskiej, dopiero przejście Zygmunta Augusta na stronę obozu reform dało szansę na realizację, choć niepełną i nie zawsze konsekwentną, haseł egzekucyjnych. Wydarzenia drugiej połowy XVI stulecia potwierdzają obserwację poczynioną dla okresu rządów Zygmunta I, kiedy to „spośród podejmowanych na sejmach reform powiodły się tylko te, które odpowiadały dążeniom zarówno monarchii, jak szlachty”: reforma monetarna i inkorporacja Mazowsza ${ }^{47}$.

Sejmowe konflikty o egzekucję miały też bezpośredni wpływ na ewolucję i funkcjonowanie systemu parlamentarnego, nie tylko w wymiarze s. $27-40$.

44 J. Dzięgielewski, Sejmy elekcyjne, elektorzy, elekcje 1573-1674, Pułtusk 2003,

${ }^{4}$ A. Sucheni-Grabowska, Monarchia dwu ostatnich Jagiellonów a ruch egzekucyjny, cz. 1: Geneza egzekucji dóbr, Wrocław 1974; eadem, Spoteczność szlachecka a państwo, [w:] Polska w epoce Odrodzenia, red. A. Wyczański, Warszawa 1986, s. 29-55; eadem, Spory królów ze szlachta w ztotym wieku, Kraków 1988; eadem, Zygmunt August. Król polski i wielki ksiązę litewski 1520-1562, Warszawa 1996.

46 I. Kaniewska, Spoteczne podstawy ruchu egzekucyjnego, [w:] Dzieje kultury politycznej $w$ Polsce, red. J. Gierowski, Warszawa 1977, s. 23-41.

47 W. Uruszczak, Sejm walny koronny w latach 1506-1540, Warszawa 1980, s. 227. 
instytucjonalnym, ale również - a może przede wszystkim - społecznym i ideowym. W świadomości współczesnych wykształciło się przekonanie, że sejm walny tworzą „trzy stany sejmujące” - król, senat i izba poselska - których współpraca i zgoda są warunkiem stanowienia prawa. Wyraźnie wzrósł prestiż sejmu: w przekonaniu szlachty powinien być nie tylko organem ustawodawczym, ale również kontrolującym działalność króla i urzędników. Zyskał również trwałe miejsce w procesie powoływania na tron nowego władcy ${ }^{48}$. Doświadczenia te w stosunkowo niedługim czasie zaowocowały dostrzegalną zmianą faktycznej roli reprezentacji poselskiej. Niewątpliwie po części było to również efektem umacniania jedności izby - skuteczność działań posłów zależała od solidarności i współdziałania reprezentantów różnych ziem. Metodą faktów dokonanych izba poszerzała zakres swojej inicjatywy ustawodawczej, wprowadzając pod obrady wątki i problemy, których nie było w planach monarchy. W zasadniczy sposób przyspieszyło to emancypację izby poselskiej spod dominacji senatorskiej, przyczyniając się jednocześnie do wzmocnienia jej prestiżu wśród szlachty. Posłowie w czasie dyskusji sejmowej często powoływali się na opinię i wolę swoich współbraci-wyborców, dość elastycznie traktując jednak dane im instrukcje i zakres udzielonych pełnomocnictw ${ }^{49}$.

Zmaganiom na forum sejmu, dzięki którym izba poselska zdobywała coraz większą samodzielność, towarzyszyły inne, wzajemnie się uzupełniające zjawiska, jak np. rozwój myśli politycznej, stanowiącej teoretyczną podbudowę działań egzekucjonistów. Bardzo mocno był w niej obecny wątek ustrojowy - refleksja nad miejscem monarchy i poszczególnych instytucji, wzajemnych relacji między nimi - wpisujące się w bieżący dyskurs parlamentarny ${ }^{50}$.

48 Już w konstytucji porokoszowego sejmu 1538 r. przyznano sejmikom i sejmowi prawo do upominania senatorów, dzierżących starostwa wbrew konstytucji, o incompatibilitas. Obie instytucje miały prawo wezwania naruszających prawo do rezygnacji z urzędu. Brak reakcji na to napominanie oznaczał dla inkryminowanego karę infamii.

49 A. Sucheni-Grabowska, Rola mandatu poselskiego w dawnej Polsce na tle porównawczym, [w:] Między polityka a kultura, red. C. Kuklo, Warszawa 1999, s. 119-137.

${ }^{50}$ Do ciekawszych przykładów należały niewątpliwie koncepcje Jakuba Przyłuskiego zamieszczone w Leges seu statuta ac privilegia Regni Poloniae... (1553), podkreślające mocno prymat prawa nad władcą oraz wysoką rolę sejmu. Przyłuski przyznawał sejmowi 
W toku ostrych debat na kolejnych sejmach wykształcały się parlamentarne procedury i obyczaje, których podstawą były ideowe pryncypia poszanowania praw wszystkich członków wspólnoty. Consensus, a nie jednomyślność - jak uznawała dawniejsza historiografia ${ }^{51}$ - co pokazuje praktyka parlamentarna doby ostatnich Jagiellonów, osiągano w drodze dyskusji, ucierania stanowisk, aż do przekonania i zamilknięcia opozycji ${ }^{52}$. Przekonanie, wyrażane między innymi przez Andrzeja Frycza Modrzewskiego, że argumenty trzeba ważyć, nie liczyć, wzmacniało wagę sejmowej dyskusji, skłaniając dyskutantów do poszukiwania rozwiązań akceptowalnych dla reszty posłów. Konieczność przekonania do swoich racji wymagała umiejętnego argumentowania, co w naturalny sposób przyczyniało się do rozwoju oratorstwa politycznego i parlamentarnej retoryki. Diariusze z czasów sejmów egzekucyjnych dostarczają bardzo wiele przykładów znakomitych, w formie i treści, przemówień poselskich. Wystąpienia i oracje wygłaszane przez Mikołaja Siennickiego czy Hieronima Ossolińskiego są do dzisiaj cytowane

bardzo rozległe kompetencje - należało doń m.in.: przestrzeganie respektowania prawa w państwie, nadzór nad rozdawnictwem urzędów i ich funkcjonowaniem, decyzje o wojnie i pokoju. Projekt Przyłuskiego, choć początkowo wspierany przez Zygmunta Augusta, ostatecznie sankcji królewskiej nie uzyskał jako zbyt daleko idący w stronę programu ruchu egzekucyjnego i przyznający zbyt szerokie prerogatywy izbie poselskiej, a tym samym szeregowej szlachcie, por:: A. Sucheni-Grabowska, Sejm w latach 1540-1586, [w:] Historia sejmu polskiego, s. 116.

${ }^{51}$ W. Konopczyński, „Liberum veto”: studium porównawczo-historyczne, Kraków 1918; H. Olszewski, Sejm Rzeczypospolitej epoki oligarchii 1652-1763: prawo, praktyka, teoria, programy, Poznań 1966 (I wyd.); K. Grzybowski, Teoria reprezentacji w Polsce epoki Odrodzenia, Warszawa 1959; Z. Wójcik, Liberum veto, Kraków 1992.

${ }^{52} \mathrm{Nie}$ jest bowiem prawdą, jak utrzymywała dawniejsza historiografia, m.in. prace Władysława Konopczyńskiego, Konstantego Grzybowskiego, a później Henryka Olszewskiego czy Zbigniewa Wójcika, że z treści konstytucji 1505 r. wynikał wprost obowiązek jednomyślnego konkludowania. Współczesne badania zdecydowanie wykluczyły tę interpretację, dowodząc, że w konstytucji nihil novi nie chodziło o jednomyślność wszystkich posłów co do podejmowanych uchwał, ale zgodę przedstawicielstw ziemskich i zgodę stanów, por.: J. Choińska-Mika, Od zgody wszystkich ku jednomyślności - „modus concludendi” sejmów polskich za ostatnich Wazów, [w:] „Vetera novis augere”. Studia i prace dedykowane Profesorowi Wactawowi Uruszczakowi, red. S. Grodziski et al., t. 1, Kraków 2010, s. 73-85. 
jako wzory parlamentarnej sztuki oratorskiej. Brak sformalizowanego regulaminu obrad umożliwiał swobodną debatę, pozwalając zarazem na czasochłonne negocjacje i poszukiwanie rozwiązań, co nie zawsze było możliwe - nie wszystkie bowiem sejmowe obrady kończyły się uchwaleniem konstytucji. Warto jednak dodać za Anną Sucheni-Grabowską, że nawet sejmy, które rozeszły się bez uchwał, określane niekiedy jako „niedoszłe”, nie były bezowocne ${ }^{53}$. Pojawiały się na nich bardzo ciekawe projekty ustrojowe (np. elekcji reprezentacyjnej), a pośród kontrowersji i sporów o konkretne rozwiązania - prawny kształt unii, status Kościoła, a nawet życie osobiste monarchy -

krystalizowały się poglądy na najważniejsze problemy państwa, wyrabiato się poczucie odpowiedzialności za nie, polerowały się maniery poselskie i krzepło poczucie międzydzielnicowej wspólnoty Polaków ${ }^{54}$.

Przeniesienie ciężaru politycznych sporów na forum sejmu i sejmików sprawiało, że to właśnie instytucje parlamentarne stały się szkołą wychowania obywatelskiego, w której kształtowały się najistotniejsze cechy polskiej kultury politycznej „złotego wieku”: niechęć do rozwiązań ekstremalnych, potrzeba informacji, poczucie odpowiedzialności, uznanie dla nadrzędności i suwerenności prawa w życiu publicznym ${ }^{55}$.

Wykształcony w czasach jagiellońskich partycypacyjny ${ }^{56}$ model kultury politycznej był swoistym posagiem, który Królestwo Polskie wnosiło przy okazji unii w Lublinie z 1569 r. do związku z Litwą i powstającej wów-

${ }^{53}$ A. Sucheni-Grabowska, Uwagi o sejmach "niedosztych”, [w:] Parlament, prawo, ludzie. Studia ofiarowane prof. Juliuszowi Bardachowi w sześćdziesięciolecie pracy twórczej, red. K. Iwanicka, M. Skowronek, K. Stembrowicz, Warszawa 1996, s. 287-294. Autorka doliczyła się w okresie 1493-1572 14 niedoszłych na 72 zwołane.

${ }^{54}$ Ibidem, s. 291

55 J. Maciszewski, Kultura polityczna Polski „ztotego wieku”, [w:] Dzieje kultury politycznej, s. 11-15.

${ }^{56}$ Wprowadzony przez amerykańskich politologów (Gabriel Almond, Sidney Verba) termin participative political culture upowszechnił Edward Opaliński. Por. E. Opaliński, 
czas Rzeczypospolitej Obojga Narodów. Polskie wzory, jak udowodnił Andrzej Rachuba ${ }^{57}$, miały dość duży wpływ na formowanie się podstaw litewskiego parlamentaryzmu. Kluczowe znaczenie miało przeprowadzenie przez Zygmunta Augusta reformy sądowej i wprowadzenie sieci powiatów. $\mathrm{Na}$ mocy unii sejm walny stał się wspólnym organem obu łączących się państw. Posłowie litewscy weszli do izby poselskiej pomiędzy reprezentantów sejmików koronnych, senat zaś powiększono o dygnitarzy z Wielkiego Księstwa Litewskiego. Przedstawicielom Litwy zapewniono równorzędne reprezentantom Korony miejsca. Porządek zasiadania i parlamentarną hierarchię określono w odrębnej konstytucji sejmowej, wybierając Warszawę na miejsce wspólnych polsko-litewskich sejmów. Decyzja ta zaważyła na dalszym rozwoju miasta, dając początek jego drodze ku stołeczności.

Nie odnosząc się w tym miejscu ani do różnicy ocen zawartej unii przez historiografię $e^{58}$, ani też do dyskusji, czy powstałe państwo było federacją 59 , warto zwrócić uwagę na kwestie mające wpływ na funkcjonowanie parlamentaryzmu, a przez to również całego systemu politycznego. W chwili zawierania unii system parlamentarny Królestwa był już w pełni ukształtowaną i dojrzałą strukturą, działającą wedle dość stabilnych reguł na trzech poziomach: centralnym - sejmu walnego, regionalnym - sejmów prowincjonalnych (sejmików generalnych), oraz lokalnym - sejmików ziemskich (partykularnych) ${ }^{60}$, zaś sejm walny był już rzeczywistym part-

Kultura polityczna szlachty polskiej w latach 1587-1652, Warszawa 1995; G. Almond, S. Verba, Civic Culture: Political Attitudes and Democracy in Five Nations, Princeton 1963.

57 A. Rachuba, Wielkie Księstwo Litewskie w systemie parlamentarnym Rzeczypospolitej 1569-1763, Warszawa 2003 - jest to podstawowa praca dla tej tematyki.

${ }^{58}$ Problem ten pojawia się w bardzo wielu pracach. Obszernie omówił historiografię XX w. M. Jucas, Unia polsko-litewska, Warszawa 2008; por. też: J. Kiaupiene, A. Zakrzewski, Unie polsko-litewskie - spojrzenie z dwóch stron, [w:] „Lex est rex in Polonia et in Lithuania". Tradycje prawno-ustrojowe Rzeczypospolitej - doświadczenie i dziedzictwo, red. A. Jankiewicza, Warszawa 2009, s. 61-85 (tam obszerna bibliografia).

59 Wacław Uruszczak wypowiada się jednoznacznie przeciwko tezie o federacyjnej strukturze Rzeczypospolitej w epoce nowożytnej, por.: W. Uruszczak, Historia państwa i prawa polskiego, Warszawa 2013, s. 207. Podobną opinię można znaleźć m.in. w syntezie U. Augustyniak, Historia Polski 1572-1796, Warszawa 2008, s. 43 i n.

${ }^{60}$ Szczegółowe informacje na temat struktury sejmu, obowiązujących w nim procedur znaleźć można w podstawowej dla tej tematyki syntezie Historia sejmu polskiego... 
nerem politycznym monarchy. Zasiadających w izbie poselskiej posłów cechowała duża niezależność oraz poczucie odpowiedzialności za i wobec współbraci - ich wyborców. Nadrzędnym jednak pryncypium, a zarazem powszechnie uznawaną zasadą było przekonanie, że to salus Reipublicae suprema lex. System parlamentarny na Litwie miał znacznie krótsze tradycje - był na tyle młody, ze nie zdołał jeszcze na trwałe wrosnąć w świadomość litewskiej szlachty. Posłom litewskim przyszło dopiero zdobywać praktykę „bycia reprezentantem”. W chwili zawierania unii nie można było rozstrzygnąć, czy i do jakiego stopnia wypracowane przez dziesięciolecia polskie wzory sprawdzą się w warunkach Rzeczypospolitej łączącej kraje o odmiennej tradycji politycznej i różnych doświadczeniach historycznych. Dopiero następne stulecia miały przynieść odpowiedzi na te pytania.

Kolejnym przełomowym momentem było bezkrólewie po bezpotomnej śmierci Zygmunta Augusta. Wyzwania, przed którymi stanęły wówczas elity państwa oraz przebieg wydarzeń zostały dość gruntownie omówione $\mathrm{w}$ historiografii ${ }^{61}$, nie ma więc potrzeby w tym miejscu ich przypominać. Warto natomiast podkreślić, że interregnum było pierwszym wspólnym dla wszystkich ziem Rzeczypospolitej doświadczeniem o randze wykraczającej poza sferę bieżącej polityki, weryfikującym w praktyce obywatelski etos i system republikańskich wartości ukształtowany w czasach jagiellońskich. Wydarzeniom bezkrólewia ton nadawała szlachta koronna, podczas gdy litewskie elity zachowywały się z wyraźnym dystansem ${ }^{62}$. To jej aktywność, wyrażona m.in. w samorzutnie zawiązywanych konfederacjach lokalnych ${ }^{63}$, wspierana postawą części senatorów, uniemożliwiła przeprowadzenie elekcji wedle wcześniejszych wzorów, sprowadzających szlachtę do roli asystującej. Pomysł elekcji viritim wychodził naprzeciw aspiracjom szlachty. Sama zaś elekcja, wbrew temu, co twierdziła dawniejsza historio-

${ }^{61}$ S. Płaza, Próby reform ustrojowych $w$ czasie pierwszego bezkrólewia: 1572-1574, Kraków 1969; idem, Wielkie bezkrólewia, Kraków 1988.

${ }^{62}$ Sytuację na Litwie i postawę Litwinów w czasie kolejnych bezkrólewi omawia w obszernym studium H. Lulewicz, Gniewów o unie ciąg dalszy. Stosunki polsko-litewskie w latach 1569-1588, Warszawa 2002.

${ }^{63}$ E. Dubas-Urwanowicz, Koronne zjazdy szlacheckie $w$ dwóch pierwszych bezkrólewiach po śmierci Zygmunta Augusta, Białystok 1998. 
grafia, odbyła się bez większych ekscesów ${ }^{64}$, choć jej przebieg różnił się nieco od porządku ustalonego podczas styczniowej konwokacji. Dyskusje na zjazdach miały charakter ożywionej debaty publicznej, której namacalnym śladem jest, będąca wciąż w użyciu, obszerna edycja pism politycznych, w większości anonimowych ${ }^{65}$. Publicystyka, w której znalazły odzwierciedlenie niemal wszystkie bieżące spory interregnum, podejmowała również refleksję na temat prawno- ustrojowych pryncypiów, wizji dobrego władcy i rządnej Rzeczypospolitej. Bezkrólewie dowiodło umiejętności samoorganizacji szlachty i dojrzałości elit szlachecko-senatorskich. Podejmowane na poziomie lokalnym i ponadregionalnym decyzje, z uchwałami konwokacji na czele ${ }^{66}$, zabezpieczyły kraj przed chaosem i wewnętrznymi konfliktami. Jednocześnie, na co zwracają uwagę badacze, wypracowywane rozwiązania niosły ze sobą nowe treści ideowe. Do takich należało przekonanie, że stan senatorski i rycerski jest „władnym decydować o porządku prawnym Rzeczypospolitej na czas, gdy urząd królewski wakował" ${ }^{67}$. Sprzyjało to, jak pokazał czas, umocnieniu rangi sejmu elekcyjnego, który - nazywany „ojcem wszystkich sejmów” - miał przewyższać znaczeniem sejmy zwyczajne. Dorobek pierwszego bezkrólewia, w tym również Artykuły henrykowskie ${ }^{68}$, był mocno osadzony w doświadczeniu i myśli politycznej epoki. Przygotowany z myślą o Henryku III Walezym dokument odwoływał się do obecnych od dawna w świadomości szlacheckiej idei: suwerenności prawa, kontraktowego charakteru władzy monarszej, prawa oporu. Jednocześnie Artykuły, gdzie dość powszechnie dostrzega się cechy ustawy zasadniczej, opisywały praktyczną realizację monarchii mieszanej, o której anonimowy autor pisał:

${ }^{64}$ J. Dzięgielewski, Sejmy elekcyjne..., s. 67-120; autor zakwestionował wiele stereotypów i obiegowych sądów na temat przebiegu nie tylko elekcji po śmierci Zygmunta Augusta, ale również późniejszych zjazdów elekcyjnych.

${ }^{65}$ Pisma polityczne z czasów pierwszego bezkrólewia, wyd. J. Czubek, Kraków 1906.

${ }^{66}$ Volumina legum, t. 2, s. 124-125 (841-843).

${ }^{67}$ J. Dzięgielewski, Sejmy elekcyjne..., s. 48.

${ }^{68}$ Treść Artykułów henrykowskich była wielokrotnie omawiana w literaturze. Ostatnio poświęcił im obszerną rozprawę D. Makiłła, Artykuty Henrykowskie (1573-1576). Studium historyczno-prawne, Warszawa 2012. 
Rzeczpospolita królestwa polskiego od przodków naszych tak jest mądrze postanowiona, iż przechodzi rozumy mądrych onych stanowiec Rzeczypospolitych, co piszą o Likurgu, Solonie, Romulusie, etc. ${ }^{69}$

Wychwalana przez publicystę mądrość miała polegać na świadomym wyborze najlepszej formy rządów - przodkowie bowiem:

moderując z tych trzech porządków, oddawszy, co wadziło, dobre wziąwszy, taką rzeczpospolitą postanowili, w której się wszystkie te trzy ordunki najdują. Jest optimatum status, jest jednego rozkazowanie, jest multitudinis. Optimatum statum trzymaj rady, popularem, stan poselski od rycerstwa; jednego te jest rozkazowanie, to jest królewskie. Wszakże nie puścili pana samopas: obyczaj rozkazowania, co zowiemy prawa, jemu spisali, do tego stróże przydali rady. Ażeby pewniejszy byli wolności swoich, urzędniki koronne do boku przysadzili obecne, a tych wszystkich przysiąg nie tylko królowi, ale i Koronie obowiązali.

Nie ulega wątpliwości, że piszący powyższe słowa był przekonany, iż polskie rozwiązania ustrojowe wcielają w życie opisywany przez wielu autorów już od starożytności i uznawany za najlepszy mieszany system sprawowania władzy. Podobna opinia pojawiła się w polskiej refleksji politycznej już w połowie XVI w., a jej źródła i związki z tradycją europejską obszernie przedstawił Janusz Ekes ${ }^{70}$. Wyniki jego badań, a także lektura diariuszy sejmowych i pism politycznych wyraźnie dowodzą, że bardzo szybko koncepcja powyższa została przyswojona przez szlachtę i w latach siedemdziesiątych należała do szlacheckiego kanonu pojęć prawno-ustrojowych.

Pierwsze bezkrólewie „domknęło” długi proces, „zachodzący zbieżnie w sferze instytucji i pojęc" ${ }^{\prime \prime 1}$, formowania się systemu politycznego, który współcześni postrzegali jako idealny ustrój mieszany, a późniejsza historiografia nazwała demokracją szlachecką, podkreślając tym samym jej

${ }^{69}$ Naprawa Rzeczypospolitej koronnej do elekcyi nowego króla, [w:] Pisma polityczne..., s. 190.

${ }^{70}$ J. Ekes, Natura - wolność - wtadza. Studium z dziejów myśli politycznej renesansu, Warszawa 2001.

${ }^{71}$ Idem, Proces kompozycji ustroju mieszanego Rzeczypospolitej, [w:] Dziedzictwo Pierwszej Rzeczypospolitej..., s. 56. 
ograniczony stanowy zasięg ${ }^{72}$. Sformułowane w 1573 r., a zaprzysiężone w 1576 r. Artykuły henrykowskie wyznaczyły ramy ustrojowe funkcjonowania państwa polsko-litewskiego, opisując (wszak nie zawsze precyzyjnie $^{73}$ ) prerogatywy najważniejszych instytucji: sejmu walnego, senatu, senatorów rezydentów. Dokument poszerzał zakres spraw, o których miał rozstrzygać sejm walny, wzmacniając również pozycję senatorów, wyznaczonych na „stróżów prawa i godności królewskiej”. W tradycyjnych ujęciach historii państwa i prawa ${ }^{74}$ dostrzega się w nich przyczyny słabości państwa i późniejszych kłopotów. Jest to jednak ujęcie dość uproszczone, które nie dostrzega pozytywnego aspektu systemu obywatelskiej partycypacji. Problem genezy trudności Rzeczypospolitej, obserwowanych zwłaszcza w drugiej połowie XVII w., jest znacznie bardziej złożony i nie można go ograniczyć do oddziaływania konkretnego aktu, nawet tak ważnego jak Artykuły henrykowskie. Zjawiska kryzysowe miały charakter ewolucyjny i dotyczyły różnych aspektów funkcjonowania państwa. Należy je rozpatrywać w powiązaniu z przeobrażeniami o charakterze społecznym, którym towarzyszyły zmiany w sferze świadomości i postaw.

Funkcjonowanie ustroju mieszanego - pisał Jan Dzięgielewski - w praktyce zależeć miało w Rzeczypospolitej w głównej mierze od poczucia powinności i kultury politycznej współdecydentów ${ }^{75}$.

${ }^{72}$ Nie rozwijając w tym miejscu wątku, warto jedynie przypomnieć, że w realiach wczesnonowożytnej Europy nie było państw spełniających kryteria „demokracji” tak jak ją definiuje nowoczesna politologia. Nawet kraje, gdzie funkcje w instytucjach sprawowali chłopi, w rzeczywistości nie dawały tej warstwie możliwości wpływania na rządy w państwie.

${ }^{73}$ Nie precyzował np. warunków zastosowania artykułu de non praestanda oboedientia, nie przewidywał sankcji za uchylanie się od rezydencji, widocznie nie biorąc pod uwagę w ogóle takiej sytuacji.

${ }^{74}$ Por.: J. Bardach, B. Leśnodorski, M. Pietrzak, Historia państwa i prawa polskiego, Warszawa 1976, praca doczekała się wielu wydań i należy do klasycznych opracowań dziejów ustroju, na których „wychowały się” pokolenia studentów.

75 J. Dzięgielewski, Procesy destrukcyjne w ustroju mieszanym Rzeczypospolitej, [w:] Dziedzictwo Pierwszej Rzeczypospolitej..., s. 71. 
A te $\mathrm{z}$ kolei ulegały systematycznej erozji. Tak jak konstruowanie monarchii mieszanej odbywało się w kilku obszarach równocześnie, tak i jej dekompozycja była wieloaspektowym procesem. Najbardziej charakterystycznym rysem tego zjawiska był postępujący rozwój systemu klientalnego i wzrost znaczenia fakcji w życiu publicznym ${ }^{76}$, a w ślad za tym przenoszenie procesu decyzyjnego z instytucji ustrojowych państwa na poziom rozwiązań pozaformalnych/pozasystemowych. W naturalny sposób prowadziło to do osłabienia rzeczywistej roli najważniejszych ogniw systemu - sejmu i powiązanych z nim sejmików - miało również wpływ na sposób ich działania oraz wykorzystywane do tych działań metody.

Początki tego procesu coraz częściej są przez historyków wiązane nie tylko ze zmianami struktury własności i powstawaniem pionowych zależności ekonomicznych wewnątrz stanu szlacheckiego, ale również ze świadomą działalnością konkretnych jednostek. Warto w tym kontekście przywołać postać Jana Zamoyskiego i jego wielkiego patrona, Stefana Batorego $^{77}$. Kanclerz i hetman w jednej osobie zbudował dzięki własnej zaradności i wsparciu monarchy „stronnictwo, które nie mogło przegrać”, używając określenia Wojciecha Tygielskiego ${ }^{78}$, przyczyniając się walnie do zaszczepienia nowych wzorów uprawiania polityki, a nawet wykorzystywania instytucji państwa i naginania prawa do realizacji prywatnych celów, czego najbardziej jaskrawym przykładem był sejm z 1585 r. i sąd nad Zborowskimi ${ }^{79}$. Zawiedzione ambicje do odgrywania pierwszoplanowej roli u boku Zygmunta III pchnęły Zamoyskiego do opozycji i walki z królem w roli trybuna ludowego, który jednakże nie tyle był autentycznym głosem szlacheckiego ogółu, co bardziej demagogiem, skutecznie wyko-

76 Temat rozwoju systemu klientalnego był wielokrotnie omawiany w polskiej historiografii w różnych kontekstach. Por. A. Mączak, Klientela, Warszawa 1994; U. Augustyniak, Dwór i klientela Krzysztofa Radziwitta (1585-1640). Mechanizmy patronatu, Warszawa 2001; Patron i dwór. Magnateria Rzeczypospolitej w XVI-XVIII wieku, red. E. Dubas-Urwanowicz, J. Urwanowicz, Warszawa 2006.

77 S. Grzybowski, Jan Zamoyski, Warszawa 1994; idem, Król i kanclerz, Warszawa 1988.

${ }^{78}$ W. Tygielski, Stronnictwo, które nie mogto przegrać, „Przegląd Historyczny” 1985, t. 76, z. 2, s. 207-231.

79 J. Dzięgielewski, Procesy destrukcyjne..., s. 71-76. 
rzystującym różne socjotechniki. Nowa rola kanclerza odzwierciedlała również zmiany w obrębie szlacheckich elit i sposobie ich działania. Wraz z wymieraniem pokolenia egzekucjonistów pojawił się w życiu publicznym nowy typ lidera sejmowego, którym był syn magnacki, a nawet sam przywódca fakcji. Więzi klientalne przekładały się na układ sił i podziały w izbie poselskiej: „zanikał” niezależny poseł, a jego miejsce zajmował klient, co w oczywisty sposób zmieniało charakter jego parlamentarnej służby. Zjawiska powyższe, dostrzegane już za panowania Zygmunta III, nasiliły się za rządów jego następców. Za Władysława IV nastąpił podział sejmikowej mapy Rzeczypospolitej na wyraźne strefy wpływów - województwa i ziemie, których sejmiki znajdowały się pod silnym wpływem, a nawet kontrolą wielkich rodów i reprezentowanych przez nie stronnictw. I choć nadal w niektórych rejonach, zwłaszcza tam, gdzie żywe były tradycje ruchu egzekucyjnego, szlachta zachowywała niezależność, to w istocie trudno było znaleźć sejmiki całkowicie wolne od fakcyjnych w tym także dworskich - wpływów ${ }^{80}$. Do nowych reguł gry dostosowywał się bowiem również monarcha ${ }^{81}$, przejmując fakcyjne metody rządzenia, co nastąpiło w pełni za czasów Jana Kazimierza.

Ugruntowywaniu się fakcji w życiu publicznym towarzyszyło osłabienie sprawności instytucji parlamentarnych, a także zachwianie równowagi wewnątrz sejmu, co nastąpiło również w czasach Władysława IV. Dążenie do przejęcia kontroli nad pracą senatu ${ }^{82}$, a także świadoma działalność liderów fakcji, prowadziły do osłabienia pozycji izby senatorskiej

${ }^{80}$ Idem, Izba poselska $w$ systemie wtadzy Rzeczpospolitej $w$ czasach Wtadystawa IV, Warszawa 1992, zwłaszcza s. 71-103.

${ }^{81}$ Obszernie problem ten omawia U. Augustyniak, Wazowie i „królowie rodacy”, Warszawa 1999, s. 196-236 (rozdział „Dwór a kraj. Ewolucja stosunków króla, szlachty i opozycji magnackiej”).

${ }^{82} \mathrm{Na}$ mocy konstytucji sejmu z 1641 r., De reddenda ratione Senatus consultorum, wprowadzono (czego się domagali liderzy izby poselskiej od 1637 r.) obowiązek składania relacji z rad senatu, co w istocie godziło w niezależność tej instytucji oraz swobodę wypowiedzi. Tekst konstytucji zob.: Volumina Legum, t. 4, s. 6 (3-4). Wzrost roli izby poselskiej kosztem senatu za Władysława IV został omówiony przez Jana Dzięgielewskiego; por. J. Dzięgielewski, Izba poselska w systemie wtadzy Rzeczypospolitej..., zwłaszcza s. 43-68. 
w systemie polityczno-ustrojowym ${ }^{83}$. Senat, który zarówno w koncepcjach doby jagiellońskiej, jak i Artykułach henrykowskich miał pełnić funkcję zwornika systemowego, pośrednika pomiędzy monarchą a narodem politycznym, w rzeczywistości został pozbawiony możliwości jej wypełniania. Erozja autorytetu instytucji senatu ułatwiała działanie fakcji i nowych liderów w izbie poselskiej. Równocześnie, ale w związku z powyższymi zjawiskami narastał proces upolityczniania sejmu, który stawał się przestrzenią rozgrywek politycznych, tracąc swoją ustawodawczą rolę. W rozgrywkach tych brał również czynny udział monarcha wraz ze swym stronnictwem, a jedną z coraz częściej stosowanych metod walki było instrumentalne wykorzystywanie parlamentarnej procedury i zwyczajów. Usztywnienie pracy sejmu przez określenie czasu trwania obrad na sześć tygodni, a następnie prawne zakazanie możliwości przedłużania debaty poza wyznaczony termin ${ }^{84}$, zamiast usprawniać sejmowy dyskurs, jak być może chcieli pomysłodawcy, uniemożliwiało go. Nieskrępowana dyskusja, a następnie ucieranie stanowisk, które były siłą sejmów egzekucyjnych, w izbie poselskiej powiększonej liczebnie po 1569 r. i w realiach nowych wyzwań politycznych, związanych głównie z prowadzeniem polityki zagranicznej i nasilaniem się napięć wewnętrznych, wymagały znacznie więcej czasu niż przewidziane prawem sześć niedziel (a faktycznie ok. 35-40 dni, bo taki był realny czas ich trwania). Praktyka pokazała, że umiejętne wykorzystywanie przepisów o zakazie prolongaty, instrukcji sejmikowych i prawa do kontradykcji (wolnego głosu) może być bardzo skutecznym narzędziem prowadzenia rozgrywki. Ceniąc sobie bardzo doraźną skuteczność, nie zastanawiano się nad długofalowymi skutkami - akceptacją w sejmowym działaniu liberum veto - co nastąpiło w drugiej połowie XVII stu-

${ }^{83}$ J. Dzięgielewski, Magnaci a senat w Rzeczypospolitej końca XVI-pierwszej połowy XVII wieku, [w:] Wtadza i prestiż. Magnateria Rzeczypospolitej w XVI-XVIII wieku, red. J. Urwanowicz, Białystok 2003, s. 23-47.

${ }^{84} \mathrm{Na}$ mocy konstytucji sejmu koronacyjnego 1633 r. zakazano skracania i przedłużania czasu trwania sejmu, wprowadzając jednocześnie obowiązek rozpoczynania konkluzji na pięć dni przed końcem obrad. Zapisano również, że przedmiotem konkluzji mogą być tylko projekty wcześniej uzgodnione w izbie poselskiej, por.: Volumina legum, t. 3, s. $373(786)$. 
lecia ${ }^{85}$. Fakt ten był jednym z najbardziej spektakularnych przeobrażeń, jakie zaszły w świadomości politycznej szlachty w ciagu zaledwie trzech pokoleń od śmierci ostatniego Jagiellona. I choć w sferze deklaratywnej szlachecki system wartości opierał się na podobnych co w XVI w. pryncypiach, to ich zakres znaczeniowy ulegał redefiniowaniu. Rzeczywisty respekt dla prawa, legalizm charakteryzujący szlachtę w epoce odrodzenia, w XVII stuleciu zaczął wyraźnie ewoluować ku coraz większemu rygoryzmowi prawnemu, co znajdowało wyraz w upartym trzymaniu się litery (nie zaś ducha) prawa oraz narastających obawach przed wprowadzaniem nowych praw. Postawy te były świadomie wykorzystywane przez zasiadających w izbie poselskiej młodych magnatów (Jerzy Lubomirski, Jeremi Wiśniowiecki, Janusz Radziwiłł), którzy „przelicytowywali szlacheckich parlamentarzystów radykalizmem republikańskich haseł" ${ }^{86}$. Eksponując zasady wolności i równości, umacniali oni swymi wypowiedziami przekonanie, że podstawowym zadaniem izby poselskiej jest obrona wolności szlacheckich, w tym zwłaszcza wolności głosu i prawa do weta. W toku parlamentarnych zmagań i pod wpływem świadomej agitacji następowało odejście od jagiellońskiej wykładni zasady zgody na rzecz bezwzględnego przestrzegania jednogłośności.

Skutki tych przeobrażeń znane są aż nadto dobrze z podręczników i niestety to one przez długie lata były w powszechnej świadomości, również badaczy zagranicznych ${ }^{87}$, kojarzone ze staropolskim parlamentaryzmem. Kryzys sejmu walnego był jednym z objawów erozji mieszanej formy rządów, widocznej już w czasach Władysława IV, a nasilającej się za panowania ostatniego Wazy. Wieloletnie wojny, w które był uwikłana Rzeczypospolita, a zwłaszcza konflikty drugiej połowy XVII w., miały istotny wpływ na dynamikę procesu. Jednak poza negatywnymi skutkami, dobrze opisanymi w literaturze, miały one również pozytywny aspekt,

85 Problem ten omawiam w artykule Od zgody wszystkich ku jednomyślności - „modus concludendi" sejmów polskich za ostatnich Wazów, por. przypis nr 51.

86 J. Dzięgielewski, Radziwittowie postami sejmów w czasach Wtadystawa IV, „Miscellanea Historico-Archivistica” 1989, t. 3, s. 28-34.

${ }^{87}$ Co stało się głównie za sprawą francuskiej edycji pracy W. Konopczyńskiego, Le liberum veto; étude sur le développement du principe majoritaire, Paris 1930. 
na który coraz częściej zwracają uwagę badacze - ujawniły trwałość etosu obywatelskiego zbudowanego na wartościach republikańskich. Przejawiał się on w mobilizacji społeczności ziemskich, przejęciu przez nie odpowiedzialności za bezpieczeństwo swoich województw i powiatów, czego dowodem były licznie odbywające się sejmiki i zjazdy, zwoływane najczęściej z lokalnej inicjatywy. Nie przestrzegano podziału kompetencji między poszczególnymi rodzajami zgromadzeń, dbając natomiast o zapewnienie im legalnych podstaw działania. Każdy zjazd zajmował się sprawami wymagającymi w danej chwili rozwiązania. Tak zwane rządy sejmikowe, które w dawniejszej historiografii były symbolem decentralizacji i słabości państwa, przez współczesnych historyków są raczej postrzegane jako przejaw umiejętności samoorganizacji, elastycznego dostosowywania istniejących rozwiązań prawno-ustrojowych do nadzwyczajnych wyzwań i potrzeb ${ }^{88}$. Szlacheckie przywiązanie do republikańskich wartości, niezależnie od dewaluacji niektórych z nich, miało jeszcze jeden aspekt - stanowiło pewną (choć jak się okazało bardzo słabą) barierę dla rozszerzania się magnackich wpływów, uniemożliwiając stosowanie bezpośrednich nacisków, „ręczne sterowanie" lokalnym życiem publicznym. Skuteczne oddziaływanie na sejmiki wymagało od magnata odpowiedniej finezji, wykorzystywania metod, które zapewniając potentatowi wpływy, nie naruszały szlacheckiego poczucia godności obywatelskiej i podmiotowości ${ }^{89}$. Rozwój wydarzeń w drugiej połowie XVII stulecia, a zwłaszcza u schyłku rządów Jana Kazimierza i za panowania Michała Korybuta, obnażył słabości instytucji ustrojowo-politycznych państwa, na czele z sejmem. Choć w sferze ideologii i deklarowanych przekonań zajmowały one nadal ważne miejsce,

88 W. Kriegseisen, Samorzad szlachecki w Matopolsce w latach 1669-1717, Warszawa 1989; J. Choińska-Mika, Pomiędzy spoteczeństwem szlacheckim a wtadza. Problemy komunikacji spoteczności lokalne - wtadza w epoce Jana Kazimierza, Warszawa 2002.

${ }^{89}$ Jak celnie zauważył swego czasu Andrzej Sulima-Kamiński: „i książęta, i oligarchowie, tacy jak Radziwiłłowie, Pacowie, Sapiehowie [...] wiedzieli, że nie mogą podjąć walki ideologicznej z kulturą obywatelską o tradycjach obywatelskich Rzeczypospolitej, Pochwata I Rzeczypospolitej, rozmowa Andrzeja Nowaka z Andrzejem Sulimą-Kamińskim, „Arcana” 1999, t. 26, z. 2, s. 5-20, s. 10; por. też: J. Choińska-Mika, Pomiędzy spoteczeństwem szlacheckim a wtadza..., s. 44-47. 
a ich formalne uprawnienia pozostały bez zmian, to w praktyce najważniejsze decyzje państwowe zapadały poza nimi. Właściwymi decydentami byli liderzy fakcji, i od układu sił pomiędzy ich ugrupowaniami zależały w dużej mierze rozstrzygnięcia głównych problemów politycznych kraju.

Ugruntowanie systemu fakcyjnego i fakcyjnych metod prowadzenia polityki zmieniło zasadniczo zakres obywatelskiej partycypacji w życiu publicznym. Wśród ziemiańskiego ogółu nie słabło przywiązanie do republikańskich ideałów, ale w zmienionym kontekście społecznym spełniały one rolę decorum, fasady, za którą kryła się zgoła „nierepublikańska” rzeczywistość. Otwarte pozostaje pytanie, czy i na ile szlachetnie urodzeni mieszkańcy Rzeczypospolitej zdawali sobie sprawę z postępującej utraty niezależności na rzecz możnych patronów? Złożoność opisywanych zjawisk nie pozwala na udzielenie prostej i jednoznacznej odpowiedzi. $\mathrm{Na}$ podstawie własnych badań ${ }^{90}$ mogę stwierdzić, że przynajmniej część obywateli dostrzegała zagrożenia płynące z umacniania się systemu fakcyjnego, nie bardzo jednak potrafiła (nie miała też możliwości) przeciwstawić się temu procesowi. Uważna analiza źródeł z epoki odsłania wiele ówczesnych lęków społecznych i frustracji. U źródeł tych nastrojów leżały nie tylko ciągnące się wojny i niepowodzenia Rzeczypospolitej na arenie międzynarodowej, ale również coraz bardziej powszechna świadomość „zacinania się” mechanizmów ustrojowych. Towarzyszyło temu poczucie zagrożenia wywołane pogłębianiem się podziałów wewnętrznych i zaostrzeniem metod oraz form walki pomiędzy stronnictwami. Niepokój ten wzmacniało pojawienie się w życiu publicznym nowej siły - wojska, które coraz wyraźniej domagało się instytucjonalnego udziału we władzy i którego ambicje były również wykorzystywane w bieżących rozgrywkach politycznych. Destabilizacja polityczna oraz pogarszanie się kondycji ekonomicznej kraju i obywateli (pauperyzacja) utrwalały poczucie zagrożenia, wobec którego obywatele coraz częściej czuli się bezradni. Lektura

${ }^{90}$ J. Choińska-Mika, Pomiędzy spoteczeństwem szlacheckim a wtadza... 
źródeł z lat sześćdziesiątych i siedemdziesiątych XVII stulecia dostarcza wielu przykładów podobnych emocji i postaw. W świetle źródeł widać również wyraźnie postępującą erozję zaufania szlachty do instytucji przedstawicielskich - sejmu walnego i posłów. Towarzyszyły temu nasilające się dążenia wspólnot ziemskich do objęcia ścisłą kontrolą funkcjonowania parlamentu i działań parlamentarzystów, coraz głośniej artykułowane postulaty przeniesienia niemal wszystkich decyzji na poziom lokalny sejmików ziemskich, a także rosnąca popularność idei sejmu konnego. W obliczu kryzysu instytucji monarchii mieszanej odwoływano się do form demokracji bezpośredniej oraz rozwiązań znanych i sprawdzonych jeszcze w średniowieczu. Rozwój wydarzeń pokazał, że były to nieuzasadnione nadzieje.

\section{Citizens' Rule: the Emergence, Growth and Decline of the "Republic of noblemen" $\left(14 / 15^{\text {th }}-17^{\text {th }} \mathrm{c}\right.$.)}

(SUMMARY)

The article examines the expansion of political rights and the changing forms of nobility's political participation in the context of constitutional transformation of the state since the late $14^{\text {th }} \mathrm{c}$. to the end of the $17^{\text {th }} \mathrm{c}$. First, there was a noted increase in political aspirations among nobility which resulted in a growing number of noblemen participating in local public/political life. This, in turn, resulted in a gradual broadening of political agenda. As a consequence, these stimulated the emergence and development of parliamentary institutions, and varying communication methods between the Crown and the localities. In addition, these processes triggered the emergence and development of a distinct civic/political culture among the nobility; one which was strongly rooted in republican ethos, respect of the law and the ideals of civic consensus.

Political system which had been created in the course of the $15^{\text {th }}$ century reached its mature, complex form in the late $16^{\text {th }}$ century. In the $17^{\text {th }}$ century the Polish - Lithuanian Commonwealth had to face new, unknown challenges, which altered the nature of noble participation in public life. The development of the clientage system, and with it the rise of magnates and their influence, was the most significant manifestation of these complex changes. As a result, there was a drastic 
shift in the decision making process: state institutions were increasingly losing their power in favour of parallel informal structures.

In effect, by the end of the $17^{\text {th }}$ century, it was the faction leaders who had the decisive say over the Commonwealth's interior and international politics. As such, the country's future and stability depended on the frail balance of power between rival fractions.

Joanna Choińska-Mika Instytut Historyczny, Uniwersytet Warszawski jmika@uw.edu.pl 